12th LUMEN International Scientific Conference Rethinking Social Action. Core Values in Practice | RSACVP 2019 | 15-17 May 2019 | lasi - Romania

\title{
The Byzantine Influence on the Italian Renaissance
}

\author{
Ionut Alexandru PLESCAU
}

https://doi.org/10.18662/lumproc. 172

How to cite: Plescau, I. A. (2019). The Byzantine Influence on the Italian Renaissance. In C. Ignatescu (ed.), 12th LUMEN International Scientific Conference Rethinking Social Action. Core Values in Practice, 15-17 May 2019, Iasi - Romania (pp. 256-262). Iasi, Romania: LUMEN https://doi.org/10.18662/lumproc.172 


\title{
The Byzantine Influence on the Italian Renaissance
}

\author{
Ionut Alexandru PLESCAU1*
}

Abstract

In the 15th century, there was a massive emigration from Byzance to Italy. Because of the Ottoman Empire, the intellectual elite of Byzantine scholars started to come with their families, by sea, to Venice and Florence. We have some Scholars émigrés who influenced the culture and the thinking process of their time, in Italy. They were Manuel Chrysoloras, Georgios Gemisthos Pletho, and others. They brought thousands of manuscripts, and with Cosmos's help, they achieved academic jobs. Even Marsilio Ficino recognized that The Platonic Academy in Florence was a project started with Gemistos Plethon, the famous Platonist professor. Also The Florence Council (1438 - 1439) was a cultural revelation between two different civilizations. By the presence of the Byzantine intellectuals in Italy, the Latins experienced a new form of meditation on the world and on the purpose of life. In particular, the return to Greek culture and ancient ideas triggered the desire of freedom in the Quattrocento thinkers. Some revolutionary ideas have taken shape in the aristocratic houses of Tuscany, Venice and Rome. It happens that some groups of scholars gather around Byzantine masters, such as Ioannes Arghyropoulos, or Bessarion. Thanks to the generosity of Cosmo de Medici and his family, many young people could afford a comfortable life dedicated to study and scientific research. Some Latin, others Byzantine.

Keywords: Renaissance; Byzantium; Greek scholars; Constantinople; quattrocento.

\section{Introduction}

Medieval history shows that the cultural heritage of Byzantium was preserved especially outside its geographical territories, especially in Italy [1]. The role that some exiles have had in Italy in the process of the Renaissance is already well known. If we remember Cardinal Bessarion (1403-1472), Ioannes Argyropoulos (1393-1487) and other noble families from

\footnotetext{
${ }^{1}$ University of Bucharest, Romania, ionutplescau@yahoo.com

Corresponding Author: Ionut Alexandru PLESCAU

Selection and peer-review under responsibility of the Organizing Committee of the conference

(c) (1) (\$) $\odot$

BY NC ND This is an Open Access article distributed under the terms of the Creative Commons AttributionNoncommercial 4.0 Unported License, permitting all non-commercial use, distribution, and reproduction in any medium, provided the original work is properly cited
} 
Constantinople, we should also remember their desire to freedom. In Italy, the strongest migration of Greeks was to Venice and Florence, with which they had historical relations since 1204. There have also been meetings between Constantinople and Rome, Padua, or Sicily.

Cooperation between Byzantium and Italy has always been complex. It is not yet fully elucidated, as it is a period in transition, such as Renaissance. Let us remember that around 1455 Johannes Gutenberg printed the Bible in numerous copies for the first time, so much information has been lost over time. What has been preserved are the letters the great intellectuals and scribes of the day sent. In fact, they were written in Latin and Greek. Many works are today in the Marciana Library in Venice, where Cardinal Bessarion carefully gathered over 1,000 manuscripts. A long list of Greek intellectuals who emigrated from the 14th century to the beginning of the 17th century was written by John Monfasani [2]. These scholars have settled in Italy with their families, or their servants, or simply by themselves.

The new life of Greeks was very difficult in Italy if we keep in mind the fact that most of them were nationalists, and besides the huge love of their homeland, they added love to their Christian - Orthodox faith. Although some have converted to Catholicism, receiving high positions in the Western Clergy. They have led a struggle to help those left behind and fallen under Ottoman rule.

\section{Theoretical Background}

The Byzantine world is an important chapter for many lovers of historical literature. And the idea that this existence would cease forever in May 1453 is untrue. It would be absurd to believe that an Orthodox Christian empire over a millennium can quit so quickly. The Dynasty of Palaeolithic emperors, Byzantine music, the quest for tranquillity in the Hebrew prayer, the greatness of the Eastern liturgical ritual are not mere aspects of a migratory population, but are the foundation of subsequent historical processes that will change the world. Byzantium had a strong intellectual elite in the last century of its existence, until 1453, an elite who collaborated in one way or another, both with the Western world and with the Arab world. But what we are currently interested in is how these scholars have managed to withstand after the dramatic year already mentioned. Many of them felt that the fall of their empire was approaching, and therefore decided to leave definitively in a safe place abroad, in which they could continue their work. 
Ionut Alexandru PLESCAU | Lumen Proceedings 9 | RSACVP2019

\section{Argument of the paper}

A very interesting article about the presence of the Greeks in Italy at the end of the fifteenth century is written by the philologist professor Concetta Bianca, currently a professor at the University of Florence. The article is titled "La presenza greca in Italia alla fine del XV secolo" [3] and deals very succinctly with the main bibliographical titles of the universal literature on the subject. The author rightly maintains that Manuel Chrysoloras's invitation to Florence to teach the Greek, the FerraroFlorentine council, and especially the fall of Constantinople, are the traditional premises for which the presence of Byzantine migrants intensified in Italy. But this presence was not a secondary one in the Renaissance process but favoured the discovery of the Greek culture, for which the Latins had great reverence but unfortunately did not know the Greek language.

Dino Geanakoplos, Augustine Pertusi, Joseph Gill, Nigel Wilson, John Monfasani believe that the Byzantines began to influence the humanist process long before the fall of Constantinople in 1453. We have the example of John Arghyropoulos who was awarded the prize in Padua in 1444, or Gheorghe of Trapezunt and Teodor Gaza that had passed through Italy since 1416. Those who became teachers in Italy were not only appreciated for the simple teaching of Greek, but also for the complete mastery of Latin and Latin oratorical instruments, as Monfasani said in his study dedicated to Teodor Gaza. From here we deduce that the profound wisdom of Greek scholars was that of knowing both their Greek and Latin languages, so that they awakened the interest of the intellectual elites in the West.

\section{Arguments to support the thesis}

Manuel Chrysoloras was brought to Florence in 1397, after a year of negotiations, with a contract of 150 florins annually for five years, but this amount rose to 250 from the next year, given the satisfaction of signoria [4]. The teacher's personality attracted many young intellectuals because they now had access to another level of wisdom. Chrysoloras has greatly simplified the traditional grammar and made a question and answer manual, „Erotemata”, printed later in 1471 [5]. Besides this linguistic guidance, this teacher remains famous for the large number of disciples he has directed. One of them was Guarino Veronese, who collected in 1452 a collection of texts in the memory of his mentor, titled "Chrysolorina" [6]. Guarino was a great lover of rhetoric, a highly valued art of his time, which he improved in Constantinople between 1403-1408 at Manuel's inducement. Of great importance in the history of Renaissance philosophy will be Leonardo Bruni, 
one of Chrysoloras's students. As Masaccio is in the painting between Giotto and Michelangelo, Bruni (educated by the Greek man Manuel Chrysoloras) sits between Petrarca and Erasmus. After studying the Greek language at Manuel, he will translate from Greek to certain well-known, even religious works, such as the writings of St. Basil the Great. This translation after St. Basil will be appreciated by circulating over 300 copies, and metaforical called „charter of liberal education”. Manuel Chrysoloras found a lot of Greek manuscripts and inscriptions in Rome, of which Constantinople was not even known [7].

Cardinal Bessarion, former Archbishop of Nicea (1403-1472), has been one of the great humanists in Italy for more than 30 years, being known among his contemporaries as a "Platonic Christian". He was born in Trapezunt on January 2, 1403 and was educated in spirit of Orthodox faith. The main mentors of his ecclesiastical education were Metropolitan Dositei, Ioannes Chortasmenos and Georgios Chrysokokkes. He actively participated in the so-called Platonic controversy, his texts playing a major role. Although, sometimes overlooked by medieval historians, he did have a substantial influence on Marsilio Ficino's mystical thinking. His importance in promoting Greek culture among the Latins is overwhelming, beginning with the Council of Ferrara - Florence until his death in 1472. From a welltrained young Orthodox monk he would become Metropolitan of Nicey in November 1437, precisely on the eve The Ferrara Synod, then in that context, will become the cardinal of the Roman Church, then the Latin Patriarch of Constantinople, a candidate for the papal chair, and will go to the eternal in 1472, being buried in the "St. Apostles "in Rome.

The arrival of John Argyropoulos (1415-1487) in Florence is another merit of Cosmo de Medici. He had more or less known intellectuals in both Constantinople and Italy. But Argyropoulos remains famous for being a master of Leonardo da Vinci for a while. This happened because of the massive migration of the Byzantine population to the West of Europe, especially to Italy, about which Cardinal Bessarion said that "Venice became almost another Byzantine." This Greek master first came to Florence with the Florentine Council, and then returned after the fall of Constantinople forever.

The idea of forming a platonic academy in Florence was inspired by Cosmo when he listened to Gemistos Plethon (1355-1452) speaking. Interestingly, the strong impression left by the old wise man. He was, in fact, considered a master, surrounded by a circle of disciples who knew some mysterious secrets that somehow contradicted Christianity. But Cosmo de Medici will not render the title of rector of this academy to Gemistos, or to John Argyropoulos, as we would have expected, but to Marsilio Ficino, the 
son of his personal doctor. Although he was very young for this position, he had a preparation and an ambition that Cosmo observed, given the philosophical value that Ficino had impregnated in his intellectual education. When we say that someone belongs to a philosophical tradition, we do not affirm that he only took some ideas and concepts from his predecessors in a mechanical way and then reaffirmed them; we believe he has taken over essential ideas from the ones before him and then gave his own form to the cultural "universe" in which he develops and adapts. An original writer is not just a philosopher who says absolutely new things. It can be original if it interprets the ones before it in an independent manner.

Plethon launched an interesting Neo-Platonist doctrine, considered speculative, rational and occult. Some Italians have taken it over and launched the spirit of renaissance, unleashed by medieval censorship [7].

\section{Arguments to argue the thesis}

In L. R. Loomis article [8] of we are told that practically, Renaissance humanism is an intellectual invention and development of the West, and the Byzantine Orient has absolutely no contribution.

\section{Dismantling the arguments against}

As a bishop of the Roman Church, Bessarion carried out a multiple activity, with many administrative successes. In 1455 and 1471 he was proposed for the pontifical chair, but he was not chosen because Rome was not prepared to have a Latin pope. In 1442 he witnessed the ratification of the union between Rome and the Jacobite Church. In 1446 he became the protector of the Greek monks in Italy and even a protector of the Franciscan monks, starting with 1458. Between 1450 and 1455 he became tied to the Pope in Bologna where he restored civil peace and restored the university in the region. He is then sent with diplomatic missions to Naples in 1455, Mantova (Lombardia) in 1458, Nuremberg and Vienna in 1460, Venice in 1463, France in 1471.

When we talk about the formation of Bessarion, we cannot miss his master Georgios Gemistos Plethon. He had participated in the Council of Ferrara - Florence and had a huge impact among the Latins there. It is due to the establishment of the Platonic Academy in Florence. This great thinker was also a guide to St. Mark of Ephesus. Rightly, "Plethon succeeded in influencing Western culture after his death. He did it through his disciples through his school in the Master. Bessarion, his most important disciple and the best hierarchical Byzantine man in the West, let him go aside. His notoriety is the place of any exemplification. John Moschos, an illustrious 
representative of the rich Moschos family in the Master, whom I remembered, continued his work at the chair, forming another generation of scholars, among whom were also Westerners. Hieronymus Charitonymus (Spartiata), one of Plethon's disciples who wrote him an obituary, became a Greek professor in Paris after he fled from the Master in 1467 and lived in Rome for a while, sustaining material and spiritually by Bessarion. Chritonymus had two famous students, Johann Reuchlin and Erasmus in Rotterdam. Plethon's legacy passed through Reuchlin to his apprentice and nephew, Philipp Melanchton (Schwartzerdt), who later became Martin Luther's right hand. Richard Hauschild believes that in this way, Mistra and Plethon influenced the Protestant Reformation in Germany to some extent.

Argyropoulos was born in Constantinople in 1415 and died in Rome in 1487. Although he had many contacts with the West, he had definitely moved to Rome after the fall of Constantinople, where he studied theology and philosophy. In Italy he will teach at the Universities of Padua, Florence, and Rome. Among his students were Peter and Lorenzo de Medici, the latter later bearing the surnames of the "Magnificent". This happened because Cosimo de Medici had been fond of our Byzantine, and that is why he preferred him to be a guardian of his grandchildren. Although Argyropoulos attended the Council of Ferrara-Florence and translated many Greek-Latin texts, his most important feature remains to be a teacher in Florence.

\section{Conclusions}

In conclusion, we can say that the cultural process of renaissance was extremely complex. Some historians, unfortunately, do not see such a powerful influence from the Byzantines, and may even deny it. They do so from a real lack of knowledge of the sources behind this process. But even those who deny the contribution of the Byzantine culture, on the other hand, assert that the memory of the Greek culture could be the basis of rebirth.

\section{References}

[1] Iorga N. Byzance après Bzyance. Bucharest. Romania: AISEE; 1971. 290 p

[2] Monfasani J. The Greeks and the Renaissance Humanism. The Society for the Study of Medieval Languages and Literature. UK:Oxford; 2012. 440 p.

[3] Bianca CC. La presenza greca in Italia alla fine del XV secolo: Firenze. Studi Slavistici. 2010; VII:245-262.

[4] Wilson NG. From Byzantium to Italy: Greek Studies in Italian Renaissance: London: Duckworth; 1992. 200 p. 
Ionut Alexandru PLESCAU | Lumen Proceedings 9 | RSACVP2019

[5] Proctor RB. The printing of Greek in the Fifteenth Century. UK: Oxford Hildesheim; 1900. 217 p.

[6] Sabbadini R. La scuola egli studi Guraino Guarini Veronese. Catania; 1896. 240 $\mathrm{p}$.

[7] Gilbert DG. Orthodoxie et culture hellénique autour de 1453: Mélanges de l'école française de Rome. Moyen-Age. 2001;113(2):787.

[8] Loomis LR. The Greek Renaissance in Italy. The American Historical Review. 1908 Jan;13(2):246-258. 